\title{
The effect of concomitant hand osteoarthritis on pain and disease activity in patients with rheumatoid arthritis
}

\author{
Emmanuel Ruiz-Medrano ${ }^{1} \cdot$ Hector Fabricio Espinosa-Ortega $^{2}$ (D) $\cdot$ Cesar Alejandro Arce-Salinas $^{1}$
}

Received: 10 December 2018 /Revised: 17 April 2019 / Accepted: 22 April 2019/Published online: 10 May 2019

(C) The Author(s) 2019

\begin{abstract}
Introduction Pain is a core complaint among rheumatoid arthritis (RA) patients, and persistent pain requires treatment adjustments according to current strategies. We aimed to quantify the impact of hand osteoarthritis (OA) on health status and residual pain in patients with RA.

Methods This cross-sectional survey compared RA patients with and without osteoarthritis of the hand. The main outcome was pain intensity. Other measurements included disease activity scores (the Disease Activity Score 28-joints; the Simplified Disease Activity Index, SDAI; the Clinical Disease Activity Index, CDAI), functional disability and self-reported quality of life, and the proportion of patients with residual pain (Patient Acceptable Symptom State, PASS).

Results Eighty-one patients were analyzed, including 39 with RA and OA and 42 with RA only. The patients were mainly women $(94 \%)$, with a median disease duration of 13 years. This group also reported a higher intensity of pain (visual analogue scale, VAS $70 \mathrm{~mm}$ vs. $30 \mathrm{~mm} ; p=0.003$ ), higher disease activity (3.89 vs. $2.88 ; p=0.001$ ), and greater functional disability irrespective of treatment and comorbidities. A strong correlation $\left(r^{2}=0.69 ; p<0.001\right)$ between pain and disease activity was observed, although no differences in pain were observed between groups according to disease activity categories. Patients with RA and OA had a higher proportion of residual pain $(59 \%$ vs. $29 \% ; p=0.006)$ even in the absence of clinical inflammation. Conclusion The coexistence of RA and hand OA is associated with distorted disease activity measurements in RA. Osteoarthritis contributes to persistent pain and greater disability in patients with RA.
\end{abstract}

Keywords Chronic pain $\cdot$ Disability evaluation $\cdot$ Osteoarthritis $\cdot$ Rheumatoid arthritis

\section{Introduction}

Rheumatoid arthritis (RA) is a chronic, systemic condition characterized by stiffness and pain in synovial joints, with a reported prevalence of between 1.0 and $1.5 \%$ in our region;

Hector Fabricio Espinosa-Ortega

fabricio.espinosa@ki.se

Emmanuel Ruiz-Medrano

emmanuel.ruizm@gmail.com

Cesar Alejandro Arce-Salinas

cesar.alejandro.arce@pemex.com

1 Division of Internal Medicine, Hospital Central Sur de Pemex, Mexico City, Mexico

2 Division of Rheumatology, Department of Medicine, Karolinska Institutet, Solna, Stockholm, Sweden the disease mainly affects young women [1]. Most patients with RA present with severe fatigue and irreversible joint damage, leading to impaired functional ability, low productivity, employment loss, increased mortality, compromised emotional well-being, and adverse impacts on quality of life [2-4]. To overcome these adverse outcomes, early and effective treatment is essential to avoid toxicity and substantial strain on global healthcare resources [5-7]; insufficient treatment is linked to persistent pain, disability progression, and other adverse outcomes, some of which may even be life-threatening [8].

Currently, any treatment strategy for RA requires an assessment of disease activity by a validated index, on which all recommendations for additions, adjustments, or changes to medication should be based [9]. Moreover, several indices have been developed to assess the multidimensional impact of RA, including those for measurement of pain, self-perception of well-being, functional ability, social 
relationships, quality of life, accumulated joint damage, the inflammatory state of the disease (also known as disease activity), and remission [10-12]. Despite effective multimodal immunosuppressive therapies, several studies have shown that many patients describe significant pain. Persistent pain has been documented not only in patients with longstanding disease but also in patients with early diagnosed RA who have received adequate treatment $[13,14]$. These findings suggest that the mechanisms underlying persistent pain are not directly related to inflammation and that other conditions may contribute to chronic widespread pain in such patients $[15,16]$. In this regard, the impact of persistent pain in the RA population and how pain influences inflammatory disease activity measurements considering that other medical conditions may intervene in patient-reported perception have rarely been investigated.

Hand osteoarthritis (OA) is a highly prevalent condition and the most common form of OA [17]. OA is a heterogeneous disease that may involve multiple joints and has several patterns of presentation, but its hallmark is the presence of nodes in both distal and proximal interphalangeal joints [18]. The presence of symptomatic hand OA is associated not only with poor quality of life and increased functional disability but also with depression, anxiety, and negative perceptions of patients regarding their disease [19]. Although the high frequency of hand OA is broadly recognized, the coexistence of this condition in RA and its impact on RA have not been fully studied. Moreover, the possible effects that hand OA may have on disease activity measurements, persistent pain, and self-reported health status are not well known. To overcome these concerns, we aimed to investigate the pain characteristics of patients with both RA and hand OA to describe the effects of hand OA on disease activity, self-reported health status, and the frequency of persistent pain in patients with RA and to compare this group with patients without hand OA.

\section{Patients and methods}

\section{Patients}

For this study, participants older than 18 years with an RA diagnosis were enrolled [20, 21]. Then, a search was conducted for a concurrent diagnosis of hand OA [22]. The exclusion criteria comprised any additional inflammatory joint disease or autoimmune illness, a previous or concurrent diagnosis of fibromyalgia or other widespread chronic pain syndromes, a history of cancer, an inability to read/write, current use of opioid drugs for pain relief, severe mental illness, moderate or severe cognitive impairment, or the use of psychotropic drugs (e.g., lithium) other than mild antidepressant drugs or low-dose benzodiazepines for mild sleep disorders. All patients signed an informed consent form, and the institutional review board on human research and the local ethics committee (Comité de Ética en Investigación, CONBIOETICA-09CEI-007-20180529) approved the study.

\section{Methods}

Patient data were collected during a one-time visit. Information related to demographics, comorbidities, and disease characteristics were recorded. Previous diagnoses of depression and/or anxiety disorders, as well as sleep disorder defined as an impairment of the ability to initiate or maintain sleep (Code G47.0, International Classification of Diseases10), were also recorded based on diagnoses established in the electronic clinical charts used in our setting. We performed a complete assessment of disease activity using four different scores: the Disease Activity Score 28-joints with erythrosedimentation rate (ESR) (DAS28-ESR), DAS28-CReactive Protein (DAS28-CRP), the Simplified Disease Activity Index (SDAI), and the Clinical Disease Activity Index (CDAI). We divided all patients into four categories according to the DAS28 cut off points [23]. Briefly, the categories were remission $(\leq 2.6)$ and low $(>2.6$ and $\leq 3.2)$, moderate $(>3.2$ and $\leq 5.1)$, and high $(>5.1)$ disease activity. Functional disability was measured with the Health Assessment Questionnaire Disability Index (HAQ-Di) Spanish version [24], and health-related quality of life was measured with the RA Quality of Life (RAQoL) questionnaire $[25,26]$. Pain was evaluated by a visual analogue scale (VAS) where patients rated pain on a $100-\mathrm{mm}$ scale between "no pain" (a score of 0 ) and "worst possible pain" (a score of 100). Furthermore, the patients indicated a global assessment of their health related to RA on a VAS, where 0 was "the best state of health related to RA," and 100 was "the worst state of health related to RA." The patients' treating physicians also rated patient global assessments on a $100-m m$ VAS. Finally, pain scores were qualified using the concept of the Patient Acceptable Symptom State in Pain (PASS) scale and were defined as the symptom scores beyond which patients consider themselves well, reflecting the concept of "feeling well" $[27,28]$.

\section{Analysis}

Descriptive statistics were determined for all data. For categorical variables, the $X^{2}$ test (or Fisher's exact test when appropriate) was used. As the distribution of pain intensity was non-normal, we conducted a Mann-Whitney $U$ test to compare continuous covariates and Spearman's rho test to analyze correlations. We required 35 patients per group to identify a clinically significant difference of $15 \mathrm{~mm}$ on the pain VAS, with an alfa of 0.05 and $80 \%$ power. The software employed was IBM/SPSS V.23. 


\section{Results}

A total of 81 patients were enrolled, including 39 with RA but no hand OA (group 1) and 42 with both RA and hand OA (group 2). The main demographic characteristics are depicted in Table 1. Patients with RA and hand OA were significantly older $(p=0.012)$. The median disease duration was 13 years, and no differences in the positivity of rheumatoid factor (RF) or anticitrullinated protein autoantibodies (ACPA) were observed. Mood and sleep disorders were present in the same proportions in both groups.

As shown in Table 2, no differences were found between the groups regarding treatment in terms of the proportions of methotrexate, biologic agents, and corticosteroid use, although the patients in group 2 showed a trend towards more frequent usage of nonsteroidal anti-inflammatory drugs (NSAIDs) (78.5\% vs. $92.6 \%, p=0.06)$. Furthermore, the impact of OA coexistence in patients with RA was better reflected in the perceptions of pain and global well-being. Patients with OA suffered a greater intensity of pain and had both poor self- and physician-reported perceptions of health status and greater functional disability. Self-reported quality of life was similar in both groups. We did not find such differences after comparing patients with and without diabetes and patients with and without high blood pressure.

Patients with OA disclosed a higher intensity of pain than those without $\mathrm{OA}$ ( $70 \mathrm{~mm}$ vs. $30 \mathrm{~mm}, p=0.003$ ). Additionally, pain scores were closely related to the number of tender joints, functional disability, and patient or physician global assessments in both groups (Table 3). Nevertheless, group 2 patients had a greater number of swollen joints, as indicated previously, but no correlation was found between this item and pain scores. Moreover, while the patients in this group were older, age was not associated with pain intensity. When the pain intensity was stratified by comorbidities, a higher intensity of pain was observed across hypertensive and menopausal patients with OA than among patients without OA, 31 vs. $62 \mathrm{~mm}(p=0.015)$ and 36 vs. $59 \mathrm{~mm}(p=0.006)$, respectively. We found no such difference among diabetic patients, 34 vs. $54 \mathrm{~mm}(p=0.56)$. Because both the swollen joint count and global health score were higher in group 2, all indices for the measurement of disease activity were higher in these patients. Thus, a positive relationship between pain intensity and disease activity was noted (Fig. 1); these differences remained when serum CRP was included instead of the ESR in the DAS28 equation or with the disease activity assessment by using the SDAI or the CDAI, which does not require any laboratory biomarker analysis.

We compared the impact of hand OA on pain scores stratified by disease activity (Fig. 2). We found no differences between the groups (with and without OA) in any disease activity category, although the pain scores of patients with a high disease activity level were significantly higher than those in all other groups $(p<0.001)$, similar to the patients in the moderate activity stratum $(p<0.001)$ (Fig. 2).

Regarding residual pain, two-thirds $(59 \%)$ of the patients without hand OA patients achieved the PASS compared with less than one-third (29\%) of the patients with hand OA, $p=$
Table 1 Demographic characteristics and comorbidities of RA patients with and without OA

\begin{tabular}{llll}
\hline & RA without OA $(n=39)$ & RA with OA $(n=42)$ & $P$ value $^{\text {Il }}$ \\
\hline Age (years [median, IQR]) & $57(47-65)$ & $60(55.8-74.2)$ & $0.012^{*}$ \\
Gender, $n$ (\% of females) & $35(89.7)$ & $41(97.6)$ & 0.19 \\
Age at diagnosis (years [median, IQR]) & $42(34-50)$ & $48.5(35-57)$ & 0.075 \\
RA duration (years [median, IQR]) & $13(5-23)$ & $13(7-24.3)$ & 0.57 \\
Body mass index (kg/m ${ }^{2}$ [median, IQR]) & $25.7(23.2-27.7)$ & $25.7(24-28.6)$ & 0.48 \\
Current or ever smoker, $n(\%$ of yes) & $5(12.8)$ & $5(11.9)$ & 1.0 \\
Type 2 diabetes mellitus $(\%$ with) & $3(7.7)$ & $11(26.2)$ & $0.028^{*}$ \\
Systemic high blood pressure (\% with) & $9(23.1)$ & $20(47.6)$ & $0.021^{*}$ \\
Menopause, $n(\%$ yes) & $26(66.7)$ & $36(85.7)$ & $0.043 *$ \\
RF, $n(\%$ of positive) & $34(87.2)$ & $31(73.8)$ & 0.16 \\
ACPA, $n(\%$ of positive) & $15(38.5)$ & $17(40.5)$ & 0.85 \\
Depression diagnosis, $n(\%)$ & $6(15.4)$ & $6(14.3)$ & 0.88 \\
Anxiety diagnosis, $n(\%)$ & $2(5.1)$ & $2(4.8)$ & 1.0 \\
Sleep disorder, $n(\%)$ & $20(51.3)$ & $14(33.3)$ & 0.1 \\
\hline
\end{tabular}

The significance is written in each of the cells. The asterisks point that the value is significant $\mathrm{P}<0.05$. Continuous variables are expressed as the median (25th-75th quartiles)

${ }^{\mathbb{}}$ Chi-squared or Fisher's exact tests were used for discrete variables, and the Mann-Whitney test was used for continuous variables. $I Q R$, interquartile range; $R A$, rheumatoid arthritis; $R F$, rheumatoid factor; $A C P A$, anticitrullinated protein antibodies 
Table 2 Comparison of disease activity, treatment, disability, and quality of life between patients with and without $\mathrm{OA}$

\begin{tabular}{llll}
\hline Item & $\begin{array}{l}\text { RA without OA } \\
(n=39)\end{array}$ & RA with OA $(n=42)$ & $P$ value $^{\text {Il }}$ \\
\hline Tender joint count & $0(0-2)$ & $1(0-2.25)$ & 0.08 \\
Swollen joint count & $0(0-0)$ & $3(0-5)$ & $<0.001^{*}$ \\
ESR, mm/h & $33(21-42)$ & $28(17-42.5)$ & 0.09 \\
CRP, mg/dl & $0.7(0.3-2.6)$ & $0.6(0.1-2.23)$ & 0.28 \\
Pain intensity, VAS, mm & $30.0(7.0-70.0)$ & $70.0(35.0-81.3)$ & $0.003^{*}$ \\
Patient's global assessment VAS, mm & $15(7-50)$ & $50(20-76.3)$ & $0.003^{*}$ \\
Physician's global assessment VAS, mm & $10(5-20)$ & $20(10-38.5)$ & $0.002^{*}$ \\
DAS-28 ESR & $2.88(2.4-3.9)$ & $3.89(3.2-4.4)$ & $0.001^{*}$ \\
DAS-28 CRP & $1.97(1.1-2.5)$ & $3.29(2.7-4.0)$ & $<0.001^{*}$ \\
SDAI & $8.2(2.6-12.6)$ & $12.3(5.9-21.3)$ & $0.005^{*}$ \\
CDAI & $4(2-9.6)$ & $10(5.0-14.1)$ & $0.001^{*}$ \\
Methotrexate use, $n(\%)$ & $8(21.4)$ & $9(21.4)$ & 0.8 \\
Steroid use, $n(\%)$ & $15(38.5)$ & $14(33.3)$ & 0.63 \\
Biological treatment, $n(\%)$ & $2(12.8)$ & $6(14.3)$ & 0.84 \\
NSAID use, $n(\%)$ & $33(78.6)$ & $36(92.3)$ & 0.08 \\
HAQ-Di score & $0.15(0.1-1.0)$ & $0.82(0.3-1.56)$ & $0.01^{*}$ \\
RAQoL score & $6.0(2.0-20.0)$ & $10.5(5.5-17.3)$ & 0.32 \\
\hline
\end{tabular}

The significance is written in each of the cells. The asterisks point that the value is significant $\mathrm{P}<0.05$.

Continuous variables are expressed as the median (25th-75th quartiles).

" Chi-squared or Fisher's exact tests were used for discrete variables, and the Mann-Whitney test was used for continuous variables. $E S R$, erythrocyte sedimentation rate; $C R P, \mathrm{C}$-reactive protein; VAS, visual analogue scale; $D A S$, disease activity index; $S D A I$, simplified disease activity index; $C D A I$, clinical disease activity index; NSAID, non-steroidal anti-inflammatory drug; $H A Q-D i$, health assessment questionnaire disability index; RAQoL, rheumatoid arthritis quality of life questionnaire
0.006 (Fig. 3). According to these observations, a higher proportion of patients with persistent pain were found among those with both conditions, RA and hand $\mathrm{OA}$,

Table 3 Correlations between pain intensity and age, disease characteristics, functional disability and self-reported quality of life

\begin{tabular}{lll}
\hline & \multicolumn{2}{l}{ Pain intensity } \\
\cline { 2 - 3 } & RA without OA & RA with OA \\
\hline DAS28 & $0.63 * * *$ & $0.69 * * *$ \\
Disease duration & 0.1 & 0.06 \\
Age at survey & -0.13 & -0.24 \\
Number of tender joints & $0.49 * * *$ & $0.42 * *$ \\
Number of swollen joints & $0.36 *$ & 0.18 \\
Patient global assessment & $0.84 * * *$ & $0.88 * * *$ \\
Physician global assessment & $0.64 * * *$ & $0.64 * * *$ \\
HAQ-Di & $0.64 * * *$ & $0.58 * * *$ \\
RAQoL & $0.67 * * *$ & $0.57 * * *$ \\
\hline
\end{tabular}

$R A$, rheumatoid arthritis; $O A$, osteoarthritis; $D A S$, disease activity score; $H A Q D i$, health assessment questionnaire disability index; RAQoL, rheumatoid arthritis quality of life questionnaire

The numbers represent linear Spearman's coefficients, $* p<0.05$, $* * p<0.01, * * * p<0.001$ highlighting the impact of the latter diagnosis on the perception of well-being in those patients who suffer from both conditions.

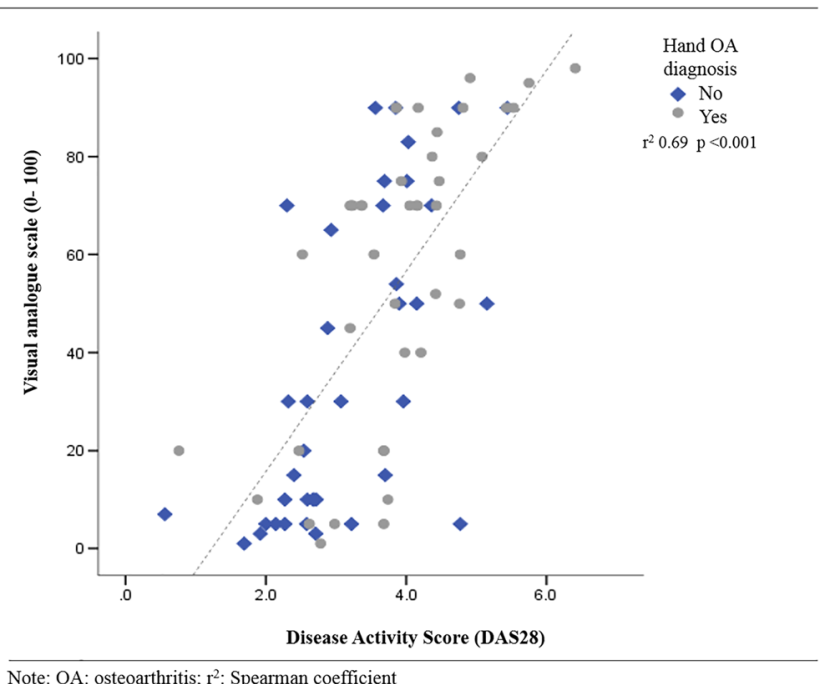

Fig. 1 Association between intensity of pain and severity of disease activity in patients with RA 


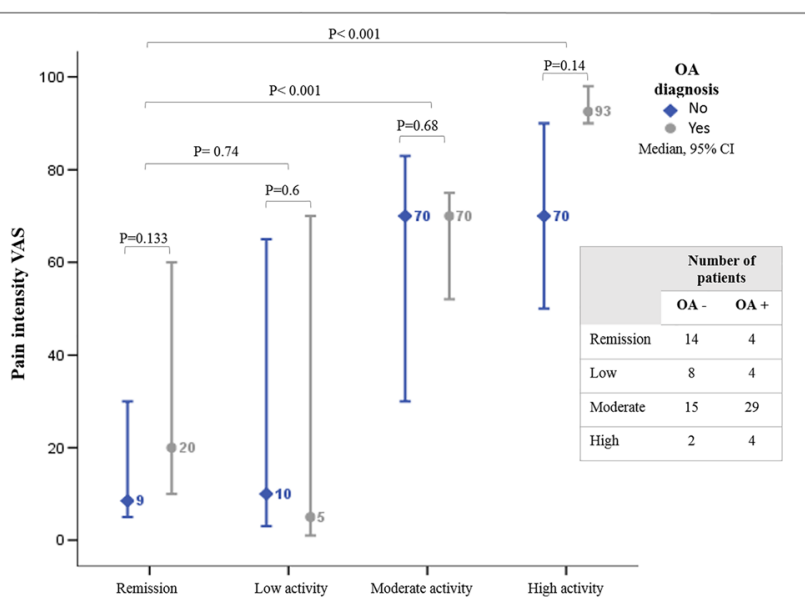

VAS: visual analogue scale. P values stand for comparisons between categories of disease activity and between $\mathrm{OA}-/ \mathrm{OA}+$ patients in VAS: visual anague scale. P values snd

Fig. 2 Differences of pain intensity in patients with RA in four categories of disease activity with and without hand OA

\section{Discussion}

Our findings demonstrate that the coexistence of $\mathrm{OA}$ in patients with RA generates important consequences in several aspects of their lives; additionally, these patients might be considered as a different population. Inoue et al. suggested that patients with late-onset RA might have a unique susceptibility to articular damage related to previous OA changes. They found that patients with both conditions presented with a larger number of painful joints and higher pain scores despite similar disease durations and adequate treatment and that these features might be related to degenerative changes unrelated to RA [29]. Our patients with RA only were younger that those with both illnesses, thus supporting this idea; unfortunately, we were not able to determine whether an OA diagnosis was established after the RA diagnosis.

Both physicians and patients often consider that pain in RA is attributable to active inflammation; nevertheless, patients

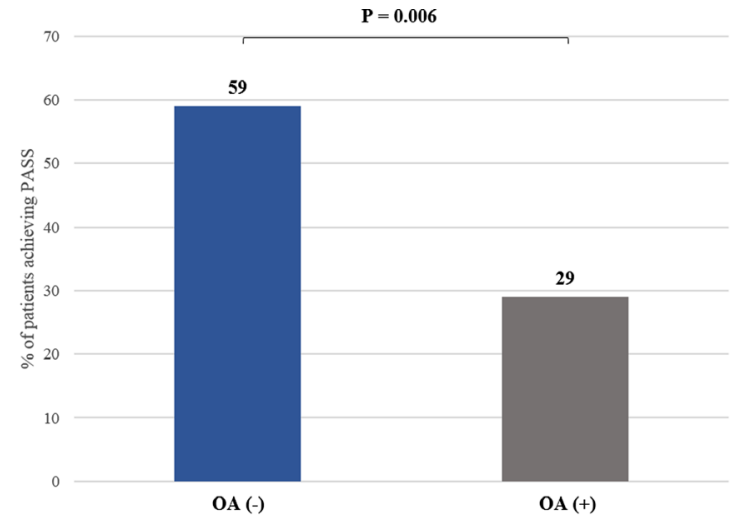

$\mathrm{P}$ value after testing proportions by $X^{2}$ test.

Fig. 3 Comparisons of RA patients with and without hand OA who achieved the patient acceptable symptom state (PASS) may experience discomfort or pain without having inflammation, even in the sites of previous episodes of arthritis, in joints with structural damage, or due to other causes [30]. We showed that the presence of OA predicts a higher intensity of pain and a poorer global assessment by the patient, although physicians' perceptions differ, assigning lower scores for global assessments when inflamed joints are not detected [31]. The measurement of RA disease activity in patients with OA could be distorted and biased towards higher scores and a lower probability of being in a state of well-being, referred to as "feeling good," through the PASS [27], with a cut off value of $40 \mathrm{~mm}$ [28]. Regardless of the index used to assess disease activity, i.e., the DAS28, DAS28-CRP, SDAI, or CDAI, with or without the inclusion of serum biomarkers, a notable proportion of patients did not achieve the PASS when OA was present. Differences in pain intensity influence the assessment of disease activity according to the number of painful joints, which is usually determined by asking a patient if pain is present when a joint is touched or squeezed, a maneuver that is clearly patient dependent. Additionally, the state of a patient's health is usually determined by the sensation of pain. In this group of patients, these indices overestimate disease activity; in contrast, previous reports in younger patients with RA indicate that these indices seem to underestimate disease activity [32, 33]. Therefore, in some specific populations, disease activity measurement indices may require an adjustment in the equation, with different weights for each included variable, reflecting the rationale for using several indices because pain and/or painful joints are weighted differently.

On the other hand, treatment decisions in RA should be supported by a pooled index that includes at least articular counts and the patient's global perception of health [34]. In the treat-to-target strategy, either using index scores as a continuous scale or disease activity intervals or categories, such scores must support disease-modifying antirheumatic drugs (DMARDs) additions or changes [35]. Further, in the specific population of patients with OA, these changes might be related to the use of more drugs or higher doses than required to maintain disease remission or low disease activity rather than determining an optimal and multimodal strategy for pain management [30]. In this regard, the treating physician's experiences may be helpful for individual patients considering that the prescription process is a complex intellectual task, which minimally includes analysis of previous experiences and recognition of individual characteristics of the disease, the clinical course, pain, well-being, accumulated articular and systemic damage, and comorbidities. Our findings suggest that activity indices must be adjusted by diminishing the items with greater subjectivity and variability, such as those influenced by pain as evaluated elsewhere using the EULAR response criteria for determining remission [36]. BelmonteSerrano performed a theoretical exercise to determine the 
contribution of each DAS28-isolated component and found an increase of 0.56 units with two painful joints and 0.79 with three painful joints, as well as 0.62 units above a VAS score of $40 \mathrm{~mm}$ for the perception of health status, which is above the PASS [37]. This finding reinforces the implications of having a chronic noninflammatory condition when physicians assess pain intensity and self-reported composite measurements in patients with RA.

Type-2 diabetes mellitus (DM2) and metabolic syndrome have been proposed as modern-day factors in the pathogenesis of OA. A study found that hand OA is associated with metabolic syndrome even after controlling for body weight [38]. Interestingly, people with high blood pressure have an increased risk of hand OA independent of obesity, and the prevalence of OA is higher in patients with DM2 than among patients without diabetes $[39,40]$. Our results seem to confirm these observations based on the comparison of pain scores between patients with and without hand OA by comorbidity strata. Regarding psychiatric conditions, pain intensity attributable to hand OA had no effect, as we did not observe differences in the frequency of such conditions in the RA with OA group.

Our study has some limitations. First, we included a small number of participants from only one center in a single geographical area, which may influence the differences in some of the analyses (e.g., quality of life) or the differences due to comorbidities. Thus, these findings must be interpreted with caution when trying to generalize them. The cross-sectional design also prevented further analysis of factors associated with variations or increases in pain perception, although the most common psychiatric conditions showed no direct impact between groups. Second, including an additional control group of patients with "primary" OA (without RA) may have revealed valuable information regarding the contribution of a noninflammatory chronic disease to health status in patients without any other rheumatic disease. However, as the aim of this study was to explore the effects of OA on patients with RA even beyond the inflammatory state, we did not include this third group. Finally, because we used the ACR clinical definition for hand OA to classify the patients, we did not differentiate between erosive and nonerosive OA in patients with RA, which is important, as many patients with erosive OA could potentially be misclassified as having RA. Nevertheless, erosive OA is easily distinguished from RA by the absence of RF and ACPA and the absence of prolonged morning stiffness and a normal ESR/CRP level [41], which all of our patients had at the time of the assessment.

In summary, we found that hand OA in a cohort with RA has important impacts due to higher intensity of pain, affecting patients' functional ability in activities of daily life as well as their own perceptions of health. OA also causes increases in disease activity scores and is therefore an important factor in residual pain, possibly resulting in the exposure of patients to potentially harmful treatments rather than pain management alone.

\section{Compliance with ethical standards}

Ethical approval All procedures in studies involving human participants were performed in accordance with the ethical standards of the institutional and/or national research committee and with the 1964 Helsinki declaration and its later amendments or comparable ethical standards. Approval was granted by the Local Bioethics Committee for Research (Comité de Ética en Investigación, CONBIOETICA-09-CEI-007-20180529).

Informed consent Informed consent was obtained from all participants included in the study.

Disclosures None.

Open Access This article is distributed under the terms of the Creative Commons Attribution 4.0 International License (http:// creativecommons.org/licenses/by/4.0/), which permits unrestricted use, distribution, and reproduction in any medium, provided you give appropriate credit to the original author(s) and the source, provide a link to the Creative Commons license, and indicate if changes were made.

\section{References}

1. Peláez-Ballestas I, Sanin L, Moreno-Montoya J et al (2001) Epidemiology of the rheumatic diseases in Mexico. A study of 5 regions based on the COPCORD methodology. J Rheumatol 38(Suppl 86): 15-20

2. Rupp I, Boshuizen HC, Jacobi CE, Dinant HJ, van den Bos GAM (2004) Impact of fatigue on health-related quality of life in rheumatoid arthritis. Arthritis Care Res 51:578-585

3. Young A, Dixey J, Kulinskaya E, Cox N, Davies P, Devlin J, Emery P, Gough A, James D, Prouse P, Williams P, Winfield J (2002) Which patients stop working because of rheumatoid arthritis? Results of five years' follow up in 732 patients from the Early RA Study (ERAS). Ann Rheum Dis 61:335-340

4. Sokka T (2009) Long-term outcomes of rheumatoid arthritis. Curr Opin Rheumatol 21:284-290

5. Monti S, Montecucco C, Bugatti S, Caporali R (2015) Rheumatoid arthritis treatment: the earlier the better to prevent joint damage. RMD Open 1(Suppl 1):e000057

6. Combe B, Logeart I, Belkacemi MC, Dadoun S, Schaeverbeke T, Daurès JP, Dougados M (2015) Comparison of the long-term outcome for patients with rheumatoid arthritis with persistent moderate disease activity or disease remission during the first year after diagnosis: data from the ESPOIR cohort. Ann Rheum Dis 74:724-729

7. Ikeda K, Cox S, Emery P (2007) Aspects of early arthritis. Biological therapy in early arthritis - overtreatment or the way to go? Arthritis Res Ther 9:211

8. Adam-Rindfleisch J, Muller D (1970) Diagnosis and management of rheumatoid arthritis. Am Fam Physician 72:1037-1047

9. Ramiro S, Sepriano A, Chatzidionysiou K et al (2017) Safety of synthetic and biological DMARDs: a systematic literature review informing the 2016 update of the EULAR recommendations for management of rheumatoid arthritis. Ann Rheum Dis 76:1093-1101

10. Pincus T, Castrejón I (2015) Are patient self-report questionnaires as "scientific" as biomarkers in "treat-to-target" and prognosis in rheumatoid arthritis? Curr Pharm Des 21:241-256

11. Smolen JS, Aletaha D, Mcinnes IB (2016) Rheumatoid arthritis. Lancet 388:2023-2038 
12. Singh JA, Saag KG, Jr SLB et al (2015) 2015 American College of Rheumatology guideline for the treatment of rheumatoid arthritis. Arthritis Care Res 68:1-26

13. Lee YC, Cui J, Lu B, Frits ML, Iannaccone CK, Shadick NA, Weinblatt ME, Solomon DH (2011) Pain persists in DAS28 rheumatoid arthritis remission but not in ACR/EULAR remission: a longitudinal observational study. Arthritis Res Ther 13:R83

14. Altawil R, Saevarsdottir S, Wedrén S, Alfredsson L, Klareskog L, Lampa J (2016) Remaining pain in early rheumatoid arthritis patients treated with methotrexate. Arthritis Care Res 68:1061-1068

15. Ranzolin A, Brenol JCT, Bredemeier M, Guarienti J, Rizzatti M, Feldman D, Xavier RM (2009) Association of concomitant fibromyalgia with worse disease activity score in 28 joints, health assessment questionnaire, and short form 36 scores in patients with rheumatoid arthritis. Arthritis Care Res 61:794-800

16. Lee YC, Chibnik LB, Lu B et al (2009) The relationship between disease activity, sleep, psychiatric distress and pain sensitivity in rheumatoid arthritis: a cross-sectional study. Arthritis Res Ther 11:1-11

17. Vos T, Barber RM, Bell B, Bertozzi-Villa A, Biryukov S, Bolliger I, Charlson F, Davis A, Degenhardt L, Dicker D, Duan L, Erskine H, Feigin VL, Ferrari AJ, Fitzmaurice C, Fleming T, Graetz N, Guinovart C, Haagsma J, Hansen GM, Hanson SW, Heuton KR, Higashi H, Kassebaum N, Kyu H, Laurie E, Liang X, Lofgren K, Lozano R, MacIntyre MF, Moradi-Lakeh M, Naghavi M, Nguyen G, Odell S, Ortblad K, Roberts DA, Roth GA, Sandar L, Serina PT, Stanaway JD, Steiner C, Thomas B, Vollset SE, Whiteford H, Wolock TM, Ye P, Zhou M, Ãvila MA, Aasvang GM, Abbafati C, Ozgoren AA, Abd-Allah F, Aziz MIA, Abera SF, Aboyans V, Abraham JP, Abraham B, Abubakar I, Abu-Raddad LJ, AbuRmeileh NME, Aburto TC, Achoki T, Ackerman IN, Adelekan A, Ademi Z, Adou AK, Adsuar JC, Arnlov J, Agardh EE, al Khabouri MJ, Alam SS, Alasfoor D, Albittar MI, Alegretti MA, Aleman AV, Alemu ZA, Alfonso-Cristancho R, Alhabib S, Ali R, Alla F, Allebeck P, Allen PJ, AlMazroa MAA, Alsharif U, Alvarez E, Alvis-Guzman N, Ameli O, Amini H, Ammar W, Anderson BO, Anderson HR, Antonio CAT, Anwari P, Apfel H, Arsenijevic VSA, Artaman A, Asghar RJ, Assadi R, Atkins LS, Atkinson C, Badawi A, Bahit MC, Bakfalouni T, Balakrishnan K, Balalla S, Banerjee A, Barker-Collo SL, Barquera S, Barregard L, Barrero LH, Basu S, Basu A, Baxter A, Beardsley J, Bedi N, Beghi E, Bekele T, Bell ML, Benjet C, Bennett DA, Bensenor IM, Benzian H, Bernabe E, Beyene TJ, Bhala N, Bhalla A, Bhutta Z, Bienhoff K, Bikbov B, Abdulhak AB, Blore JD, Blyth FM, Bohensky MA, Basara BB, Borges G, Bornstein NM, Bose D, Boufous S, Bourne RR, Boyers LN, Brainin M, Brauer M, Brayne CEG, Brazinova A, Breitborde NJK, Brenner H, Briggs ADM, Brooks PM, Brown J, Brugha TS, Buchbinder R, Buckle GC, Bukhman G, Bulloch AG, Burch M, Burnett R, Cardenas R, Cabral NL, Nonato IRC, Campuzano JC, Carapetis JR, Carpenter DO, Caso V, Castaneda-Orjuela CA, Catala-Lopez F, Chadha VK, Chang JC, Chen H, Chen W, Chiang PP, Chimed-Ochir O, Chowdhury R, Christensen H, Christophi CA, Chugh SS, Cirillo M, Coggeshall M, Cohen A, Colistro V, Colquhoun SM, Contreras AG, Cooper LT, Cooper C, Cooperrider K, Coresh J, Cortinovis M, Criqui MH, Crump JA, Cuevas-Nasu L, Dandona R, Dandona L, Dansereau E, Dantes HG, Dargan PI, Davey G, Davitoiu DV, Dayama A, de la CruzGongora V, de la Vega SF, de Leo D, del Pozo-Cruz B, Dellavalle RP, Deribe K, Derrett S, Des Jarlais DC, Dessalegn M, deVeber GA, Dharmaratne SD, Diaz-Torne C, Ding EL, Dokova K, Dorsey ER, Driscoll TR, Duber H, Durrani AM, Edmond KM, Ellenbogen RG, Endres M, Ermakov SP, Eshrati B, Esteghamati A, Estep K, Fahimi S, Farzadfar F, Fay DFJ, Felson DT, Fereshtehnejad SM, Fernandes JG, Ferri CP, Flaxman A, Foigt N, Foreman KJ, Fowkes FGR, Franklin RC, Furst T, Futran ND, Gabbe BJ, Gankpe FG, Garcia-Guerra FA, Geleijnse JM, Gessner
BD, Gibney KB, Gillum RF, Ginawi IA, Giroud M, Giussani G, Goenka S, Goginashvili K, Gona P, de Cosio TG, Gosselin RA, Gotay CC, Goto A, Gouda HN, Guerrant R, Gugnani HC, Gunnell D, Gupta R, Gupta R, Gutierrez RA, Hafezi-Nejad N, Hagan H, Halasa Y, Hamadeh RR, Hamavid H, Hammami M, Hankey GJ, Hao Y, Harb HL, Haro JM, Havmoeller R, Hay RJ, Hay S, Hedayati MT, Pi IBH, Heydarpour P, Hijar M, Hoek HW, Hoffman HJ, Hornberger JC, Hosgood HD, Hossain M, Hotez PJ, Hoy DG, Hsairi M, Hu H, Hu G, Huang JJ, Huang C, Huiart L, Husseini A, Iannarone M, Iburg KM, Innos K, Inoue M, Jacobsen KH, Jassal SK, Jeemon P, Jensen PN, Jha V, Jiang G, Jiang Y, Jonas JB, Joseph J, Juel K, Kan H, Karch A, Karimkhani C, Karthikeyan G, Katz R, Kaul A, Kawakami N, Kazi DS, Kemp AH, Kengne AP, Khader YS, Khalifa SEAH, Khan EA, Khan G, Khang YH, Khonelidze I, Kieling C, Kim D, Kim S, Kimokoti RW, Kinfu Y, Kinge JM, Kissela BM, Kivipelto M, Knibbs L, Knudsen AK, Kokubo Y, Kosen S, Kramer A, Kravchenko M, Krishnamurthi RV, Krishnaswami S, Defo BK, Bicer BK, Kuipers EJ, Kulkarni VS, Kumar K, Kumar GA, Kwan GF, Lai T, Lalloo R, Lam H, Lan Q, Lansingh VC, Larson H, Larsson A, Lawrynowicz AEB, Leasher JL, Lee JT, Leigh J, Leung R, Levi M, Li B, Li Y, Li Y, liang J, Lim S, Lin HH, Lind M, Lindsay MP, Lipshultz SE, Liu S, Lloyd BK, Ohno SL, Logroscino G, Looker KJ, Lopez AD, Lopez-Olmedo N, Lortet-Tieulent J, Lotufo PA, Low N, Lucas RM, Lunevicius R, Lyons RA, Ma J, Ma S, Mackay MT, Majdan M, Malekzadeh R, Mapoma CC, Marcenes W, March LM, Margono C, Marks GB, Marzan MB, Masci JR, Mason-Jones AJ, Matzopoulos RG, Mayosi BM, Mazorodze TT, McGill NW, McGrath JJ, McKee M, McLain A, McMahon BJ, Meaney PA, Mehndiratta MM, MejiaRodriguez F, Mekonnen W, Melaku YA, Meltzer M, Memish ZA, Mensah G, Meretoja A, Mhimbira FA, Micha R, Miller TR, Mills EJ, Mitchell PB, Mock CN, Moffitt TE, Ibrahim NM, Mohammad KA, Mokdad AH, Mola GL, Monasta L, Montico M, Montine TJ, Moore AR, Moran AE, Morawska L, Mori R, Moschandreas J, Moturi WN, Moyer M, Mozaffarian D, Mueller UO, Mukaigawara M, Murdoch ME, Murray J, Murthy KS, Naghavi P, Nahas Z, Naheed A, Naidoo KS, Naldi L, Nand D, Nangia V, Narayan KMV, Nash D, Nejjari C, Neupane SP, Newman LM, Newton CR, Ng M, Ngalesoni FN, Nhung NT, Nisar MI, Nolte S, Norheim OF, Norman RE, Norrving B, Nyakarahuka L, Oh IH, Ohkubo T, Omer SB, Opio JN, Ortiz A, Pandian JD, Panelo CIA, Papachristou C, Park EK, Parry CD, Caicedo AJP, Patten SB, Paul VK, Pavlin BI, Pearce N, Pedraza LS, Pellegrini CA, Pereira DM, Perez-Ruiz FP, Perico N, Pervaiz A, Pesudovs K, Peterson CB, Petzold M, Phillips MR, Phillips D, Phillips B, Piel FB, Plass D, Poenaru D, Polanczyk GV, Polinder S, Pope CA, Popova S, Poulton RG, Pourmalek F, Prabhakaran D, Prasad NM, Qato D, Quistberg DA, Rafay A, Rahimi K, Rahimi-Movaghar V, Rahman S, Raju M, Rakovac I, Rana SM, Razavi H, Refaat A, Rehm J, Remuzzi G, Resnikoff S, Ribeiro AL, Riccio PM, Richardson L, Richardus JH, Riederer AM, Robinson M, Roca A, Rodriguez A, Rojas-Rueda D, Ronfani L, Rothenbacher D, Roy N, Ruhago GM, Sabin N, Sacco RL, Ksoreide K, Saha S, Sahathevan R, Sahraian MA, Sampson U, Sanabria JR, Sanchez-Riera L, Santos IS, Satpathy M, Saunders JE, Sawhney M, Saylan MI, Scarborough P, Schoettker B, Schneider IJC, Schwebel DC, Scott JG, Seedat S, Sepanlou SG, Serdar B, Servan-Mori EE, Shackelford K, Shaheen A, Shahraz S, Levy TS, Shangguan S, She J, Sheikhbahaei S, Shepard DS, Shi P, Shibuya K, Shinohara Y, Shiri R, Shishani K, Shiue I, Shrime MG, Sigfusdottir ID, Silberberg DH, Simard EP, Sindi S, Singh JA, Singh L, Skirbekk V, Sliwa K, Soljak M, Soneji S, Soshnikov SS, Speyer P, Sposato LA, Sreeramareddy CT, Stoeckl H, Stathopoulou VK, Steckling N, Stein MB, Stein DJ, Steiner TJ, Stewart A, Stork E, Stovner LJ, Stroumpoulis K, Sturua L, Sunguya BF, Swaroop M, Sykes BL, Tabb KM, Takahashi K, Tan F, Tandon N, Tanne D, Tanner M, 
Tavakkoli M, Taylor HR, te Ao BJ, Temesgen AM, Have MT, Tenkorang EY, Terkawi AS, Theadom AM, Thomas E, ThorneLyman AL, Thrift AG, Tleyjeh IM, Tonelli M, Topouzis F, Towbin JA, Toyoshima H, Traebert J, Tran BX, Trasande L, Trillini M, Truelsen T, Trujillo U, Tsilimbaris M, Tuzcu EM, Ukwaja KN, Undurraga EA, Uzun SB, van Brakel WH, van de Vijver S, Dingenen RV, van Gool CH, Varakin YY, Vasankari TJ, Vavilala MS, Veerman LJ, Velasquez-Melendez G, Venketasubramanian N, Vijayakumar L, Villalpando S, Violante FS, Vlassov VV, Waller S, Wallin MT, Wan X, Wang L, Wang JL, Wang Y, Warouw TS, Weichenthal S, Weiderpass E, Weintraub RG, Werdecker A, Wessells KRR, Westerman R, Wilkinson JD, Williams HC, Williams TN, Woldeyohannes SM, Wolfe CDA, Wong JQ, Wong H, Woolf AD, Wright JL, Wurtz B, Xu G, Yang G, Yano Y, Yenesew MA, Yentur GK, Yip P, Yonemoto N, Yoon SJ, Younis M, Yu C, Kim KY, Zaki MES, Zhang Y, Zhao Z, Zhao Y, Zhu J, Zonies D, Zunt JR, Salomon JA, Murray CJL (2015) Global, regional, and national incidence, prevalence, and years lived with disability for 301 acute and chronic diseases and injuries in 188 countries, 1990-2013: a systematic analysis for the global burden of disease study 2013. Lancet. 386:743-800

18. Thaper A, Zhang W, Wright G et al (2005) Relationship between Heberden's nodes and underlying radiographic changes of osteoarthritis. Ann Rheum Dis 64:1214-1216

19. Hodkinson B, Maheu E, Michon M, Carrat F, Berenbaum F (2012) Assessment and determinants of aesthetic discomfort in hand osteoarthritis. Ann Rheum Dis 71:45-49

20. Arnett FC, Edworthy SM, Bloch DA et al (2007) The American Rheumatism Association 1987 revised criteria for the classification of rheumatoid arthritis. Arthritis Rheum 31:315-324

21. Aletaha D, Neogi T, Silman AJ, Funovits J, Felson DT, Bingham CO III, Birnbaum NS, Burmester GR, Bykerk VP, Cohen MD, Combe B, Costenbader KH, Dougados M, Emery P, Ferraccioli G, Hazes JMW, Hobbs K, Huizinga TWJ, Kavanaugh A, Kay J, Kvien TK, Laing T, Mease P, Ménard HA, Moreland LW, Naden RL, Pincus T, Smolen JS, Stanislawska-Biernat E, Symmons D, Tak PP, Upchurch KS, Vencovský J, Wolfe F, Hawker G (2010) 2010 rheumatoid arthritis classification criteria. Arthritis Rheum 62: 2569-2581

22. Altman R, Alarcón G, Appelrouth D et al (1990) The American College of Rheumatology criteria for the classification and reporting of osteoarthritis of the hand. Arthritis Rheum 33: $1601-1610$

23. Fransen J, Van Riel PLCM (2005) The Disease Activity Score and the EULAR response criteria. Clin Exp Rheumatol 23(Suppl 39): S93-S99

24. Cardiel M, Abello-Banfi M, Ruiz-Mercado F, Alarcón-Segovia D (1993) How to measure health status in rheumatoid arthritis in nonEnglish speaking patients: validation of a Spanish version of the Health Assessment Questionnaire Disability Index (Spanish HAQDI). Clin Exp Rheumatol 11:117-121

25. Tijhuis GJ, De Jong Z, Zwinderman AH et al (2001) The validity of the Rheumatoid Arthritis Quality of Life (RAQoL) questionnaire. Rheumatology (Oxford) 40:1112-1119

26. Pacheco-Tena C, Reyes-Cordero G, Mckenna SP, Ríos-Barrera VA (2011) Adaptation and validation of the Rheumatoid Arthritis Quality of Life Scale (RAQoL ) into Mexican Spanish [in Spanish]. Reumatol Clin 7:98-103

27. Perrot S, Bertin P (2013) "Feeling better" or "feeling well" in usual care of hip and knee osteoarthritis pain: determination of cut off points for patient acceptable symptom state ( PASS ) and minimal clinically important improvement ( $\mathrm{MCII}$ ) at rest and on movement in a national multicentre cohort study of 2414 patients with painful osteoarthritis. Pain. 154:248-256

28. Tubach F, Ravaud P, Martin-Mola E et al (2012) Minimum clinically important improvement and patient acceptable symptom state in pain and function in rheumatoid arthritis, ankylosing spondylitis, chronic back pain, hand osteoarthritis, and hip and knee osteoarthritis. Arthritis Care Res 64:1699-1707

29. Inoue K, Shichikawa K, Nishioka JSH (1987) Older age onset rheumatoid arthritis with osteoarthritis. Ann Rheum Dis 46: 908-911

30. Van De Laar M, Pergolizzi JV Jr, Mellinghoff H et al (2012) Pain treatment in arthritis-related pain: beyond NSAIDs. Open Rheumatol J 6:320-330

31. Suarez-Almazor ME, Conner-Spady B, Kendall CJ, Russell AS, Skeith K (2001) Lack of congruence in the ratings of patients' health status by patients and their physicians. Med Decis Mak 21: 113-121

32. Fleischmann R, Van Der Heijde D, Koenig AS et al (2015) How much does Disease Activity Score in 28 joints ESR and CRP calculations underestimate disease activity compared with the Simplified Disease Activity Index? Ann Rheum Dis 28:1132-1137

33. Matsui T, Kuga Y (2011) Comparison of composite disease activity indices for rheumatoid arthritis. Mod Rheumatol 21:134-143

34. Gaujoux-viala C, Mouterde G, Baillet A et al (2012) Evaluating disease activity in rheumatoid arthritis: which composite index is best? A systematic literature analysis of studies comparing the psychometric properties of the DAS, DAS28, SDAI and CDAI. Joint Bone Spine 79:149-155

35. Smolen JS, Aletaha D, Bijlsma JWJ, Breedveld FC, Boumpas D, Burmester G, Combe B, Cutolo M, de Wit M, Dougados M, Emery P, Gibofsky A, Gomez-Reino JJ, Haraoui B, Kalden J, Keystone EC, Kvien TK, McInnes I, Martin-Mola E, Montecucco C, Schoels M, van der Heijde D, for the T2T Expert Committee (2010) Treating rheumatoid arthritis to target: recommendations of an international task force. Ann Rheum Dis 69:631-637

36. Son KM, Lee SY, Il SY, Choi J, Kim HA (2017) Contribution of subjective Disease Activity Score 28 (DAS28) components to the response to treatment of rheumatoid arthritis. Clin Rheumatol 28: $1221-1227$

37. Belmonte-Serrano M (2008) Is the DAS28 score the best method to estimate the disease activity in rheumatoid arthritis? Clinimetric considerations and simulated cases [in Spanish]. Reumatol Clin 4: 183-190

38. Visser AW, De Mutsert R, Le Cessie S et al (2015) The relative contribution of mechanical stress and systemic processes in different types of osteoarthritis: the NEO study. Ann Rheum Dis 74: $1842-1847$

39. Niu J, Clancy M, Aliabadi P, Vasan R, Felson DT (2017) Metabolic syndrome, its components, and knee osteoarthritis: the Framingham Osteoarthritis Study. Arthritis Rheum 69:1194-1203

40. Louati K, Vidal C, Berenbaum F, Sellam J (2015) Association between diabetes mellitus and osteoarthritis: systematic literature review and meta-analysis. RMD Open 1:e000077

41. Belhorn LR, Hess EV (1993) Erosive osteoarthritis. Semin Arthritis Rheum 22:298-306

Publisher's note Springer Nature remains neutral with regard to jurisdictional claims in published maps and institutional affiliations. 